\title{
Critical Evaluation of Allowance for Resources Wastefulness in the Construction Industry
}

\author{
Fapohunda, J. A. (Corresponding Author) \\ Department of Building Technology, Yaba College of Technology \\ Yaba, Lagos State, Nigeria \\ Tel: 234-80-3119-5911Ｅ-mail: bldrfapo@yahoo.com \\ Ogunsanmi, O. E. \\ Department of Building, University of Lagos \\ Akoka, Lagos State, Nigeria \\ E-mail: Bode_ogunsanmi2004@yahoo.co.uk \\ Omoniyi, S. S. \\ Department of Architecture, Olabisi Onabanjo University \\ Ago Iwoye, Ogun State, Nigeria \\ E-mail: unbeatableng@yahoo.com \\ Fatokun, A. O. \\ Department of Building Technology, Yaba College of Technology \\ Yaba, Lagos State, Nigeria \\ E-mail: ajibolaoladipo@yahoo.com
}

Received: August 22, 2011

doi:10.5539/jsd.v5n1p76
Accepted: November 24, $2011 \quad$ Published: January 1, 2012

URL: http://dx.doi.org/10.5539/jsd.v5n1p76

\begin{abstract}
In the construction industry, project site operatives see resources wastefulness as inevitable. Moreover, there is often an absence of appropriate resources to support waste management. This notion makes participants to a project exhibit nonchalantly towards optimising the "nuclear use" construction resources. It is also an important realisation that, these resources, materials, manpower and machinery are not only increasing in cost daily but also becoming increasingly scarce. Previous research has shown that more than $30 \%$ of construction resources often end up wasted during the building production process. These emanate the rational to evaluate the issues of 'budgeting for resources waste syndromes' in building industry, and to identify the appropriate measure of achieving optimal utilisation of these resources. This paper identifies the behavioural features of site participants in resources wastefulness and provides an incentive framework for achieving efficient utilisation of construction resources, which include self-fulfilment, belong-ness and appraisal. Adequate implementation of the framework proposed will not only be beneficial to the construction practitioners and researchers, but will also enhance construction sustainability and lean thinking in this building industry-regenerating era.
\end{abstract}

Keywords: Behavioural features, Building production, Construction resources, Incentives, Waste syndromes

\section{Introduction}

Teo and Loosemore (2001:271) emphasised, in their "Theory of Waste Behaviour in the Construction Industry", that the management of wastes is perceived as a low project priority; also, there is an absence of the appropriate resources and incentives to support the management. It was identified by Egan (1998), in "the Rethinking Construction Report", that the construction industry as a whole is under achieving, and to achieve its set target, the industry will need to make radical changes in the process through which it delivers its products. Though, the 
main challenge in resources optimisation problem is to identify the best option towards optimal resource utilisation for each construction activity in the project, from a set of feasible alternatives that may include possible combinations of: construction method, which represents possible construction technologies and materials; team formation, which depicts feasible compositions of construction labour and equipment; and to overtime policy, which describes the length and time of work shifts on site, (Kandii \& Khalied, 2006). Hence, to achieve an enhanced radical changes in the construction product delivery, there is a significant need to evaluate the scenarios of Budgeting for resources Waste Syndromes, (BWS) in the industry and to minimise its effects on the construction product.

Budgeting for waste in construction industry imply allowance for wastefulness of materials, machinery, manpower, cost and time, during pre-contract and construction stages of the project. Thus, the inefficient use of labour, materials, plant and equipment is usually due to the proactive believe that waste has been built into the resources during production information preparation, specification writing and construction cost budgeting. This is seldom the case resulting in predominant losses of time and cost during construction process. In Constructing Excellence $(2003 ; 2006)$, it was explained that wastes due to motion, transportation, repetition, overproduction and defects will never add value to construction products. However, the majority of construction wastefulness stems not only from to bad workmanship, inadequate supervision, improper planning or poor organisation of a site, but usually because of the concept of pre-notion that wastage is normal. These beliefs often makes the construction participants exhibit nonchalant attitude to resources utilisation.

Among the critical factors identify by Fapohunda et al. (2006) that hinder construction site managers in efficient resources utilisation based on syndromes of "budgeting for wastes' of construction resources in the industry are: the provision or allowance of resources for wastage; envisage that wastes will occur during the construction stage; the intrinsic perception of the construction participants on the production information and the belief that wastes has been built-in into the resources' specifications, estimated quantity, and construction costs. Thus, construction resources wastefulness is assumed inevitable, couple with an absence of the appropriate resources to support management. Therefore, this paper critical evaluates the scenarios of allowance for resources wastefulness in the construction industry and identifies the behavioural features of site participants in resources wastefulness and provide an incentive framework for achieving efficient utilisation of construction resources.

To obtain valid and reliable findings on rationales for budgeting or allowance of resources wastefulness in the construction industry and able to establish solutions for minimisation, this research is triangulated using structure questionnaire. Also, interviewed is conducted to authenticate the questionnaire's survey findings. Finally, conclusions are drawn based on the findings obtained from the experienced construction personnel in the UK construction industry.

\section{Research Methodology}

This research work was carried out using triangulation method. The rationale for the triangulation method is to enhance the validity and reliability of the research findings; the advantages a research method were improved by the other and disadvantages of a method were negated by the other. Information and data were gathered using the fact from literature, augmented with structured questionnaires and interview.

Questionnaires were distributed to construction personnel: Project Managers, Site managers and Quantity Surveyors. To enhance the quality of the response, the questions are framed on open, closed and attitude based. These questions were measured using the point scale, Likert scale rated from $1-5$, that ranged from "strongly disagree" to "strongly agree" and "very low" to "very high"; some questions were to be responded with YES or NO while others are open and opinion seeking questions. One hundred and two questionnaires were collected and analysed by using SPSS, and the findings are presented in section 3.1.

For validity and reliability purposes, oral interview with structured questionnaire were administered. The respondents were solicited to comment on each question. Eight construction personnel were interviewed, while the comments were tape recorded, transcribed and thereafter correlated together. The interview information and emergence themes and facts were collated by means of NVivo statistical tool and the deduced facts are presented in section 3.2 .

\section{Data Collection, Analysis and Discussion of Findings}

The views of Clough and Nutbrown (2002), Bryman (2004), Field (2005), Bryman and Cramer (2005) helped in the questionnaires administration, and Silverman (2005), Creswell (2008) and Tronchin (2009), aided the interview data collection, analysis and interpretation. 


\subsection{Quantitative Research Survey Study}

\subsubsection{Demography of Questionnaires' Survey Respondents}

This section presents the demography of the respondents that returned complete questionnaires, and the analysed data are illustrated in Tables 1 and 2, and Figures 2 and 3.

\subsubsection{Managerial Status of the Participants and the Years of Experience}

Table 1 shows that representatives from 9 distinct construction managerial levels participated in the questionnaires survey. As presented in Figure 1, the total respondents that had more than five years' managerial experience in the construction industry are $84 \%$; of these, $57 \%$ have more than 15 years managerial work experience and $27 \%$ have between 5 - 15 years. Only $16 \%$ have less than 5 years' managerial experience, though this does not indicate their unawareness in the problems associated with resources utilisation in the industry. Table 1 and Figure 1, illustrate that, the percentage of project site managers /senior site managers in the respondents is $40 \%$, the site managers and contract managers/senior contract mangers are $29 \%$ and $10 \%$ respectively. All the project directors, planning managers, design managers, and senior building managers in the survey have not less than 15 years' managerial experience in the construction industry.

These results indicate that the respondents are significantly experienced and rationally have wide knowledge in the construction industry.

3.1.3 Geographical Zones Covered and the Number of Employees in the Respondents' Organisations:

(i) Coverage: Table 2 indicates the geographical zones which the respondents' organisations operate in the UK. $84 \%$ of the organisations are in 8 or more geographical zones. The majority of the organisations are in $10-11$ geographical zones, $66 \%,(28 \%,+38 \%)$, while only $16 \%$ have construction sites in less than 8 geographical zones.

(ii) Numbers of Employees: Based on the results obtained as shown in Table 5.2, 85\% of the respondents' organisations have more than 400 employees, while only $15 \%$ have below 400 employees. These results in Table 2 show that the respondents are representation of several organisations in different geographical zones in UK, and the majority of the construction organisations had above 400 permanent employees.

This study is technically divided into three main sub-headings:

1) Factors that Contributes to "Budgeting for Resources' Wastes Syndromes" The factors evaluated are grouped under:
(a) Materials,
(b) Manpower,
(c) Machinery,
(d) Production Information,
(e) Design Team, and
(f) Site Management;

2) Allowance for Wastes of different types of Construction Resources;

3) Resources' Wastes in-built in different Production Information;

\section{1) Factors that contributes to "budgeting for resources' wastes syndromes"}

This part evaluates, and ascertains the factors that contribute to budgeting for resources wastefulness in the construction industry. Several factors were outlined for consideration, and respondents rated these factors between Very High Contribution, (5) and No Contribution, (0)

This section establishes the following:

a) a rank order of the factors in order of significance;

b) factors that lead to BWS;

c) ascertaining factors that need to be avoided toward resources' wastes minimisation;

d) ascertaining the factors that need attention towards resources' wastes reduction during construction production process.

\section{Discussion of findings on factors that contributes to "budgeting for resources wastefulness"}

The results obtained from the analysed data are presented in Table 3. The data outcome shows that the contributions of all the factors considered are significant, having values above average. Also, there are indications that resources wastefulness largely occur through several means of allowances and provisions. However, the contributions of the design team in resources' wastes assumption and allowances are paramount in comparison with other factors evaluated, (the contributions due to materials, manpower, machinery, production information, and site management). 
The details in Table 3 ( $\mathrm{a}-\mathrm{f}$ ) show the ranked order of the factors considered in each group. All five factors considered on Design team are rated $61 \%$ and above apart from a factor in each group, (Table 3a), while the results indicate that all the nine factors considered under plant and equipment, (Table 3e), have a lesser tendency for budgeting for their wastefulness, the values of the factors' ranges from $46 \%$ to $55 \%$. Therefore, it could be deduced from these scenarios that, budgeting for resources wastefulness is significantly predominant during construction production process due to the design team and their production information provided for construction works. However, these questionnaire survey findings are further verified through interview research survey, and the report is based on these questions:

"What are the rationales for budgeting for resources wastefulness in the construction industry, and how could these predicaments be minimised to ensure optimal resources utilisation and significant wastes management?"

\section{Reliability and validity tests' statistics}

The reliability and validity tests' statistics calculated, (Tables $4(\mathrm{a}-\mathrm{f})$ ) revealed that the responses collected and items considered on issues of "budgeting for resources wastefulness" are valid and reliable, apart from items "design not to manufacturers standard - materials off cut", (Table 4a), and "weather condition - work delay" (Table 4b). However, this fact does not absolutely indicate that these factors do not contribute to budgeting for resources wastefulness. These results are further investigated during the interview research survey, among other issues.

\section{2) Allowance for wastes of different types of construction resources}

This section verifies and differentiates the magnitude of physical or visible resources wastes that are allowed for in various construction resources. The results show that less solid or visible wastes' assumptions are often made for plant and equipment utilisation with combined "strongly agreed and agreed rate of $22 \%$. In comparison, materials are rated highest, $68 \%$ followed by manpower, $44 \%$ (Table 5). The results presented in Table 5 show that the allowance of materials' wastes is approximately half the total resources' wastes allowance for construction works. Comparing the ratio of occurrence, the ratio is approximately 1:2:3, (Me: Mp: Me). The interactive charts of the occurrences illustrated in Figure 5 and Figure 6 present the details of the respondents' agreement. Figure 6 shows the higher agreement to wastes due to materials, while the wastes due to machinery utilisation have a lower agreement percentage.

Though, allowance of materials' wastes is the highest in percentage of occurrence; however, the majority of the occurrences are highly possible due to utilisation of other construction resources: manpower, machinery and other factors such as design team and production information.

\section{3) Resources' wastes in-built of different production information}

This section evaluates and ascertains the level of contribution of every package of production information towards budgeting for resources' wastes. From the analysed data, the percentages of "strongly agreed" and "agreed" were summed together. The results show that, "Architectural Drawings and Specifications" has maximum allowance for resources wastefulness with a respondents' rate of $56 \%$. This is followed by: Structural Drawings and Specifications, 53\%; Bill of Quantities, 52\%; Mechanical Drawings and Specifications, 50\%. The production information of which resources wastefulness is least envisaged to occur is "Electrical Drawings and Specifications", with rate of $45 \%$. These results are presented in Table 5 and Figure 7.

\subsection{Interview Research Survey Study Report}

From the questionnaires survey result obtained, fifteen (15) respondents indicated interest in participating in this research further investigation. Every respondent had an equal opportunity of being interviewed. The rationale is that, all the respondents are significantly experienced and rationally have wide knowledge in the construction industry (Figure 1). The additional reasons are:

a) All the respondents are practising professionals, directly involved in management of construction resources on construction sites.

b) The result of questionnaires survey demography indicates that all the personnel had above ten years of experience as managers with requisite responsibilities on resources utilisation in different multinational construction organisations.

Eight construction site personnel were consulted unbiased and interviewed. The status and years of experience of the respondents are presented in Table 10.

This interview research study investigates, identifies, evaluates, and ascertained the rationales for budgeting for resources' wastes in the construction industry and established the modalities of reducing the causal-effects. 
Based on the interview conducted, emerged findings are presented in the subsequently:

The main question addressed is,

"How and why do the design and construction teams budget for resources wastefulness?"

The various sub-questions asked from which findings were deduced during interview are:

a) What are the factors that contribute to allowance for or budgeting for wastes in the construction industry?

b) Why should the design and construction teams budget for wastes?

c) How can BWS construction participants' beliefs be changed and resources wastefulness be minimised?

\subsubsection{Causes of Budgeting for Wastes' Syndromes}

The identifiable causes of Budgeting for Wastes' Syndromes in Construction industry are:

1) Inability to ensure labour efficiency: Often, labour is over-procured due to the inability to ensure efficiency, while in many cases to achieve timely delivery without delay that could occur due to inefficiency of labour or utilisation of semi-skilled ones. However, this often causes labour redundancy.

2) Ambiguous and inadequacy of production information: BWS occurs when there is a lack of adequate production information from the design team and the consultants, and inadequate time to prepare annotated production information.

3) Rigidity of the design team over production information. On many occasions, the design team is inflexible over specifications and often value project aesthetics over resources salvage, the designers habitually design and specify with less consideration of construction and materials utilisation implication, thus drive causes for BWS.

4) Construction project location: Significant numbers of construction projects sites environment are not conducive, wastes are often allowed for due to the failure of machine and equipment resources which may occur during the construction process.

5) Lack of skilled manpower resulting in the utilisation of semi-skilled workforce: Lack of adequate and experienced skilled labour in construction industry often causes the need to allow for waste to offset semi-skilled workforce mistakes. More so, site managers do over procure labour due to an inability of ensuring or ascertaining the efficiency of the available semi-skilled worker that will be employed.

6) Alterations and modifications: Habitual alterations in design concept(s) affect resources that have been procured contributes to resources' wastes that emanate BWS. In effect, many resources' wastes and allowance for wastefulness are due to the pre-assumption that alteration(s) and modification(s) will occur to the design concept, (drawings and specifications), during production process. Therefore, to prevent the delay this might cause during the production process, a quantity of resources are budgeted for and procured.

7) Avoidance of liquidation damage: Often avoidance of liquidation damages result in BWS, and procurement of resources in excess of actual quantity that will be required to complete a task. Significant quantities, (percentages) are theoretically added to resources that are visibly required; this is to prevent the probable effect of unforeseen circumstances that could cause delays.

8) Short project delivery time: Consciously quantities of resources are budgeted for by site managers to allow for possible wastes, when there is a time constraint to deliver projects. In respect, site managers are thus after time rather than cost or wastage to meet the delivery time. In many instances, site managers over procure resources to prevent any shortage that might arise during the construction process that could cause delay. That is, the site managers order in excess to prevent an inability to obtain materials promptly, when there is shortage and to avoid delay in delivery.

9) External Factors Control Limitation: Site managers have limitations to implement perfection during project executions because of a few external factors; such as environmental and weather conditions. These factors cannot be adequately controlled, which often warrants budgeting for wastefulness.

10) Lack of new innovative skilled workers: Construction site managers often budget for resources wastefulness to limit the effects of tradition workers' inefficiency or semi skilled workers in applying new innovation or new construction methods required for a task.

11) Labour only sub-contractors' carefree attitude: Labour only contractors have the tendency of wasting materials since these contractors have somewhat fewer concerns with cost implication of the construction materials as a resource. Thus, additional resources somewhat allow resources sufficiency. However, if the 
contractors were allowed to supply and fix the materials, there is an increased tendency for them to be more careful in order to maximise profit.

12) Client unaware or nonchalant attitude: The majority of construction clients are unaware of the cost implication of resources' wastes that often occur during construction production process, otherwise, the clients will be more conscientious about finding possible measures of avoiding or minimising the "non-value-adding wastes", BWS, or re-occurrence in consequent project.

\subsubsection{Rationales that Make the Site Participants Belief that the Resources' Wastes are Inevitable}

From the interview conducted, the rationales that make the site participants belief that the resources' wastes are inevitable are:

a) The construction environment and due to environmental factors which cannot be predicted precisely.

b) Wastes occurrence due to unavoidable human errors.

c) Most project sites are in congested or remote areas.

d) Due to insufficient time to plan adequately at project inception, also, the urgency of the need of the project, and delivery time constraints.

e) Lack of adequate experienced and skilled labour in the construction industry.

3.2.3 Factors that will Significantly Reduce Construction Participants' Beliefs and Resources Wastefulness

The solutions deduced that will significantly reduce construction participants' beliefs that resources' wastes are unavoidable are:

1) Motivation and Incentives towards wastes reduction: The beliefs of site participants on construction resources' wastes cannot be easily changed and an incentive in the form of a financial bonus to construction participants could significantly enhance efficiencies, thus reducing the beliefs on resources wastefulness. The workers need to be aware that, there are rewards for saving construction resources wastefulness; this will significantly enable them to be careful in resources utilisation.

2) Setting and striving to achieve wastes reduction targets: There is a need for organisations to set wastes' targets. A resources' wastes reduction target needs to be set and participants need to strive to achieve it. The construction participants should be aware that there are tolerable wastes; this will considerably enable the workers to be more careful in resources utilisation.

3) Reliable record and information on similar previous project executed: There is need for adequate information retrieval database on construction projects; where reference can be made, checked, and related to current project; efficiency, mistakes, correction and measure is practically applicable to avoid problems or obstacles during the construction process. Construction participants being aware that there is such a reference document, their beliefs about waste(s) will be challenged and they will become mindful of resources utilisation.

4) Training towards executing project efficiently and be resourceful: Construction participants need to be trained towards how to execute project tasks confidently and resourcefully.

5) Awareness of resources' wastes implication and wastes reduction benefits: Participants need to know the implications of efficient and inefficient resources utilisation. All construction participants need to be implicitly inducted towards wastes awareness, avoidance, and minimisation. In addition, workers need to know the cost implication of resources wastefulness; the effect, and the benefits of wastes reduction.

\section{Summary of the Research Study and the Topical Issues}

Wastes' Syndromes, (WS) are more or less a tradition in the construction industry. Many resources' wastes occur due to the pre-assumption that alterations and modifications will happen to the design concept, construction drawings, and specifications. To prevent the adverse effect on construction resources utilisation, several wastes are been budgeted for and procured. The major contributor to WS is the design team. It is the design team that produces production information that often causes chain contribution, WS. In addition, the Site managers can only control so much, but, there is a limitation to enforce perfection, especially, environmental factors that cannot be adequately controlled. However, among the major solutions towards reduction of wastes is the involvement of the construction site manager to vet production information before being adopted for construction. In this regard, waste in all forms might have been identified and there will be less to budget for. If the designer designs to manufacturers' standards, there is a high possibility that WS will be minimal. It is noteworthy that site management can only control and there is a limitation in enforcing perfection on construction resources utilisation, since construction site environmental factors and its impediments cannot be 
efficiently controlled.

This research study evaluated the scenarios of budgeting for resources wastefulness that perpetuate resources inefficiencies during construction production process. The study critically investigates this BWS concept from the perspective of the construction participants' Knowledge, Attitudes, and Perceptions based on the beliefs, attitudes, and the behaviour of the construction workers towards construction resources utilisation and wastes.

This study assessed the factors, grouped under five categories. These groups are materials, manpower, machinery, production information, design team, and site management. In this study, the circumstances and scope of different types of construction resources; wastes; and resources; wastes in-built of different production information were affirmed.

Several significant facts emerged which are presented in tables, figures and interactive charts that made possible the establishment of the "beliefs of site participants on construction resources"; "the attitudes of the site workers towards resources wastage"; and, "the behaviour of the construction operatives towards resources' wastes".

Among the facts deduced are: the site operatives believe that the construction resources wastage is normal and wastes have to be budgeted for during production information preparation. Thus, these facts influence the workers in showing a carefree attitude towards resources utilisation.

The data and results validity and reliability were confirmed with tests' statistics. In addition, further investigations were carried out through an interview research study, to establish the modalities of the avoidance or reduction of BWS, before or during construction works. Interview was conducted to ascertain the rationales for allowing for wastefulness of construction resources, and solutions to avert or reduce the scenarios for budgeting for resources wastes are established. Table 11 presents the summary of the causes, rationales and solutions proposed on the scenarios of BWS in the construction industry.

From the analysed data and coherence responses from the both questionnaire and oral interview surveys, the following issues can be drawn from BWS scenarios in the construction industry:

Nuclear-Use Resources: Construction resources wastage should be attributed to the efficient usage of labour and machinery not only on materials. It is evident that enormous labour and plant as resources are been utilised inefficiently during construction processes. Egan (1998:15) indicated that " $40-60 \%$ of labour is effectively utilised, with not less than $10 \%$ of materials being wasted, and up to $30 \%$ of construction works being reworked or repeated during the construction production process".

Unconscious Wastage: During the preparation of construction production information, the design team should always take cognisance of some wastefulness of resources that occur unconsciously. In British Standard, BS 6079-1 (2002), Office of Government Commerce, OGC - 02 (2007), and Constructing Excellence (2003, 2006), it was emphasised that, the conscious and unconscious occurrences of resources inefficiency are significantly due to one or a combination of the following: negligence, an incautious attitude, carelessness, indulgence, poor supervision, and in addition to project manager's inefficiency or ineffectiveness.

Incentive Scheme And Reward: Construction participants have to be motivated toward the use of resources, (Accel-Team, 2005). Creation of incentive scheme and rewards to workers toward efficient resources utilisation. Combinations of incentive schemes could be applied. Some suggested useful schemes are:

a) Appraisal for fulfilment,

b) Goal setting for efficient resources utilisation,

c) Holiday compensation,

d) Bonus pay and other reward able means for hard working,

e) Waste reduction benefit scheme,

f) Target or task job for time saving scheme and

g) Damage free and carefulness award scheme.

Training and Seminar: Construction participant need to be trained through seminars or other appropriate means. The training should emphasise the need for efficiency and that resources wastefulness is abnormal. Employees should be tailored toward efficient utilisation of construction resources, not only on materials usage, but on the labor and machinery efficiency and effectiveness. During the training, the workers should be aware of different incentive schemes available on project for efficient and effective performance of duty.

Harmonisation of Production Information (PI): There is need for proper harmonisation of PI before any 
project commences to avert avoidable resources wastage thereafter; in addition predominance of variations and alterations need to be minimised towards enhancement efficient utilisation of materials, labour and plant.

Self Esteem and Belongness: Construction operatives have to be encouraged to reach potential. The greater self-esteem, self-respect and belongness the employee attained, the better the employee contribution and commitment to the development of the organisation and the project.

Manpower Resource and Source of Wastage: In construction industry, manpower needs to be treated with keen interest. There are resources which could be wasted and source to waste other resources.

Open Door Policy: The site personnel should always bridge the communication gap and operate an open door policy. These will allow operatives to be ready to shear knowledge and contribute meaningfully to smooth running of an organisation and project.

Knowledge Sharing: Provision of time for knowledge shearing. This could start from the project manager and other site personnel by instigate skill in problem solving, creativity and resource utilisation among other accrued potential.

Integration of Construction Resources: There are interweaved contributions of wastage from different resources; materials (Ma), manpower (Mp) Machinery (Me), Site Management (Ms), Design Team (Dt) and Production Information (PI)/ Thus there is a need for integration of each element toward effective and efficient building production. Omoniyi, Ali and Fapohunda, (2004), stated that, the cost of both plant and labour are proportional to the time and quality expected, while it is important to consider the make up of construction time and resources utilisation and wastage on site, and its effects on labour productivity and output.

\section{Conclusion and Recommendation}

The research was carried out using triangulated method, incorporating both structured oral interviews and a structured questionnaire. The authors identified a conceptual framework for BWS, and the construction waste resources (CWS) in relation to construction industry and national endowment. Thus, the causes of this resources wastefulness were grouped into materials $(\mathrm{Mm})$; manpower $(\mathrm{Mp})$; machinery $(\mathrm{Me})$; and site management (Ms); design team (DT); and production information (PI). This paper identified and provided an incentive framework for achieving efficient utilisation of construction resources, which includes self-fulfilment, belong-ness and appraisal for fulfilment among others. In addition, this research study established the effects of budgeting for waste resources and more importantly its reduction.

The effective implementation of the framework proposed in this research paper will significantly enhance the building resources wastes' reduction, lean construction and sustainable construction in the industry.

\section{References}

Accel-Team. (2005). Employee Motivation, Motivation in the Work Place - Theory and Practice. UK.

Accel-Team. (2011). [Online] Available: http://www.accel-team.com/motivation/index.html (July 01, 2011)

Bryman, A. (2004). Social Science Research Methods (2nd Ed.). Oxford: Oxford University Press.

Bryman, A. \& Cramer, D. (2005). Quantitative analysis with SPSS 12 and 13: A guide for social scientist. London: Routledge.

BS 6079-1. (2002). Guide to project management. May 2002. London: BSI.

Clough, P. \& Nutbrown, C. (2002). A student's guide to methodology. London: Sage Publications.

Constructing Excellence. (2003a). Eleven case studies: Profit together from process improvements using CLIP.
(Online).
UK:
BRE.
[Online]
Available:

http://www.bre.co.uk/filelibrary/Vol_2_CLIP_Case_Study_Booklet_30-04 05.pdf (September 1, 2006)

Constructing Excellence. (2006a). Lean construction - does it work? Measuring excellence. Constructing Excellence in the Built Environment, 2, 7.

Creswell, J. W. (2008). Qualitative, quantitative and mixed methods approaches. UK: Sage Publishers.

Egan, J. (1998). Rethinking Construction News release, UK, Department of environment, transports and Regions. [Online] Available:

http://www.constructingexcellence.org.uk/pdf/rethinking\%20construction/rethinking_construction_report.pdf

(May 5, 2011)

Omoniyi, S. S., Fapohunda, J. \& Alli, A. A. (2004). Mason Output in the Construction Industry Using Activity 
Sampling Method. International Journal of Ultra Scientist and Physical Sciences, 16, 1.

Fapohunda, J., Stephenson, P., Griffith, A. \& Chileshe, N. (2006b). Budgeting for waste syndrome (BWS) within the construction industry, In: Baldwin, A., Hui, E., and Wong, F. (Eds.) CD-ROM. Conference Proceedings of the CIB W89-International Conference on Building Education and Research BEAR 2006 - Construction Sustainability and Innovation Conference, 10-13 April 2006, Kowloon, Shangri-la, Hong Kong (pp. 114 - 121)

Field, A. (2005). Discovery statistics using SPSS for window. London: Sage Publication.

OGC - 02. (2007). Project organisation roles and responsibilities: Achieving excellence in construction procurement guide. Office of Government Commerce.UK: Crown Ltd.

Silverman, D. (2005). Doing qualitative research: A practical handbook (2nd Ed.). London: Sage Publications.

Teo M. M. M. \& Loosemore M. (2001). A Theory of Waste Behaviour in the Construction Industry, Construction Management and Economics, 19, Taylor and Francis Ltd. [Online] Available: http://ideas.repec.org/a/taf/conmgt/v19y2001i7p741-751.html (May 2, 2011)

Trochim, William M. (2006). The research methods knowledge base (2nd Ed). [Online] Available: http://www.socialresearchmethods.net/kb/contents.php (May 2, 2011)

Table 1. Respondents "Site Management Positions"; on, the "Years of Experience of the Respondents as a Manager" in the construction industry

\begin{tabular}{|c|c|c|c|c|c|c|c|c|}
\hline & \multicolumn{4}{|c|}{$\begin{array}{l}\text { Years of Experience as a Manager } \\
\text { in Construction Industry }\end{array}$} & \multirow[t]{2}{*}{ Total } & \multirow[t]{2}{*}{$\%$} & \multirow[t]{2}{*}{ Cumulative $\%$} \\
\hline & & $\begin{array}{l}\text { Less } \\
\text { than } 5\end{array}$ & $5-10$ & $11-15$ & $\begin{array}{c}\text { Above } \\
15\end{array}$ & & & \\
\hline \multirow{9}{*}{ 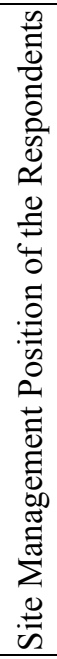 } & $\begin{array}{l}\text { 1. Project Managers/Senior } \\
\text { Project Managers }\end{array}$ & 0 & 6 & 8 & 27 & 41 & 40 & 40 \\
\hline & 2. Site managers & 12 & 2 & 7 & 9 & 30 & 29 & 69 \\
\hline & $\begin{array}{c}\text { 3. Contract } \\
\text { Managers/Senior Contract } \\
\text { Managers }\end{array}$ & 0 & 2 & 0 & 8 & 10 & 10 & 79 \\
\hline & $\begin{array}{c}\text { 4. Quantity } \\
\text { Surveyors/Senior Quantity } \\
\text { Surveyors }\end{array}$ & 2 & 2 & 0 & 2 & 6 & 6 & 85 \\
\hline & 5. Project Directors & 0 & 0 & 0 & 5 & 5 & 5 & 90 \\
\hline & 6. Planning Managers & 0 & 0 & 0 & 4 & 4 & 4 & 94 \\
\hline & 7. Section Managers & 2 & 0 & 0 & 0 & 2 & 2 & 96 \\
\hline & 8. Design Managers & 0 & 0 & 0 & 2 & 2 & 2 & 98 \\
\hline & $\begin{array}{l}\text { 9. Senior Building } \\
\text { Managers }\end{array}$ & 0 & 0 & 0 & 2 & 2 & 2 & 100 \\
\hline & Total & 16 & 12 & 15 & 59 & 102 & 100 & \\
\hline & $\%$ & 16 & 12 & 15 & 57 & 100 & & \\
\hline & Cumulative \% & 16 & 28 & 43 & 100 & & & \\
\hline & & $16 \%$ & & $84 \%$ & & & & \\
\hline
\end{tabular}


Table 2. Geographical zones which the Respondents' Organisations Operate in the UK

\begin{tabular}{|c|c|c|c|c|c|c|c|c|c|c|c|c|c|c|}
\hline & & \multicolumn{10}{|c|}{$\begin{array}{c}\text { Geographical Zones Of Which The Respondents Organisation are located In } \\
\text { UK. }\end{array}$} & \multirow{2}{*}{$\begin{array}{c}\text { Total } \\
\text { No. }\end{array}$} & \multirow[t]{2}{*}{$\%$} & \multirow{2}{*}{$\underset{\%}{\mathrm{Cum}}$} \\
\hline & & Four & Five & Six & Seven & Eight & Nine & Ten & Eleven & Twelve & Thirteen & & & \\
\hline \multirow{6}{*}{$\begin{array}{l}\text { No. Of Employees In } \\
\text { The Organisation } \\
\text { Presently In UK. }\end{array}$} & $\begin{array}{l}101- \\
150\end{array}$ & 0 & 0 & 0 & 0 & 0 & 2 & 0 & 0 & 0 & 0 & 2 & 2 & 2 \\
\hline & $\begin{array}{l}151- \\
200 \\
\end{array}$ & 0 & 0 & 0 & 0 & 2 & 0 & 0 & 0 & 0 & 0 & 2 & 2 & 4 \\
\hline & $\begin{array}{l}201- \\
250 \\
\end{array}$ & 0 & 0 & 0 & 0 & 0 & 0 & 2 & 0 & 0 & 0 & 2 & 2 & 6 \\
\hline & $\begin{array}{c}251- \\
300 \\
\end{array}$ & 0 & 0 & 0 & 3 & 2 & 2 & 0 & 0 & 0 & 0 & 7 & 7 & 13 \\
\hline & $\begin{array}{l}350- \\
400 \\
\end{array}$ & 0 & 0 & 0 & 0 & 0 & 0 & 2 & 0 & 0 & 0 & 2 & 2 & 15 \\
\hline & $\begin{array}{c}\text { Over } \\
400 \\
\end{array}$ & 1 & 3 & 2 & 7 & 1 & 0 & 25 & 39 & 5 & 4 & 87 & 85 & 100 \\
\hline \multicolumn{2}{|l|}{ Total } & 1 & 3 & 2 & 10 & 5 & 4 & 29 & 39 & 5 & 4 & 102 & 100 & \\
\hline \multicolumn{2}{|l|}{ Percent } & 1 & 3 & 2 & 10 & 5 & 4 & 28 & 38 & 5 & 4 & 100 & & \\
\hline \multicolumn{2}{|c|}{ Cumulative Percent } & 1 & 4 & 6 & 16 & 21 & 25 & 53 & 91 & 96 & 100 & & & \\
\hline & & \multicolumn{4}{|c|}{$16 \%$} & \multicolumn{6}{|c|}{$84 \%$} & & & \\
\hline
\end{tabular}


Table 3. Factors that contributes to budgeting for resources wastefulness

\begin{tabular}{|c|c|c|c|}
\hline Table 3(a) Due to Design Team & $\%$ & Table 3(b) Due to Materials & $\%$ \\
\hline (Mean) & 63 & (Mean) & 58 \\
\hline 1. Variation order delay - that may affect other works & 69 & $\begin{array}{l}\text { 1. Design not to manufacturers' standard - materials off } \\
\text { cut }\end{array}$ & 66 \\
\hline 2. Waiting time for alteration order & 67 & 2. Irregular shapes - off-cut & 66 \\
\hline $\begin{array}{l}\text { 3. Communication gap between design \& construction } \\
\text { teams }\end{array}$ & 65 & 3. Materials damage on stock piling & 64 \\
\hline $\begin{array}{c}\text { 4. Predominant meeting on } \\
\text { variations/alterations/modifications }\end{array}$ & 61 & 4. Specifications uncertainty & 59 \\
\hline \multirow[t]{9}{*}{$\begin{array}{l}\text { 5. Delay in inspection to proceed to another stage of } \\
\text { work }\end{array}$} & 54 & 5. Ordering of materials for usage - unreturned to store & 58 \\
\hline & & 6. Adverse weather - drying shrinkage & 58 \\
\hline & & 6. Design engineers' faults & 57 \\
\hline & & 7. Weather conditions - materials spoilage & 55 \\
\hline & & 7. Pilferage - security lapses & 55 \\
\hline & & 8. Residual and spillage during work in progress & 55 \\
\hline & & 8. Planning error(s) & 54 \\
\hline & & 9. Transit wastes - brake \& spillage & 52 \\
\hline & & 10. Quantity surveyor(s) mistakes & 49 \\
\hline Table 3(c) Due to Manpower & $\%$ & Table 3(d) Due to Site Management & $\%$ \\
\hline (Mean) & 57 & (Mean) & 55 \\
\hline 1. Double handling & 65 & 1. Poor site organisation & 62 \\
\hline 2. Rework due to mistake(s) & 64 & 2. Inadequate project/site planning & 57 \\
\hline $\begin{array}{l}\text { 3. Unskilled operation - increasing the time of } \\
\text { completion }\end{array}$ & 60 & 3. Poor communication system - that leads to time lag & 56 \\
\hline $\begin{array}{l}\text { 4. Wrong construction method - leading to delay /time } \\
\text { lapse }\end{array}$ & 58 & $\begin{array}{l}\text { 4. Delay in decision making and operation order - time } \\
\text { lag }\end{array}$ & 56 \\
\hline $\begin{array}{l}\text { 5. Waiting time for materials to use - Redundancy } \\
\text { period }\end{array}$ & 56 & $\begin{array}{l}\text { 5. Poor selection of materials and labour procurement } \\
\text { systems }\end{array}$ & 56 \\
\hline 6. Lack of co-ordination within or among gang(s) & 56 & $\begin{array}{l}\text { 6. Inexperience technicality types required for the } \\
\text { project }\end{array}$ & 55 \\
\hline $\begin{array}{l}\text { 7. Right operation for wrong work - leading to delay or } \\
\text { rework }\end{array}$ & 54 & 7. Poor operation control- leading to delay or rework & 55 \\
\hline 8. Weather conditions - leading to delay & 54 & 8. Inadequate monitory system & 55 \\
\hline $\begin{array}{l}\text { 9. Insufficient tools and equipment to use - waiting } \\
\text { time }\end{array}$ & 52 & $\begin{array}{l}\text { 9. Poor project planning And Schedule that leads to } \\
\text { wastage }\end{array}$ & 54 \\
\hline \multirow[t]{2}{*}{ 10. Traffic between plant position to operation place } & 51 & $\begin{array}{l}\text { 10. Lack of sufficient motivation - to boast operative } \\
\text { morale }\end{array}$ & 52 \\
\hline & & 11. Poor schedule of resources & 51 \\
\hline Table 3(e) Due to Production Information & $\%$ & Table 3(f) Due to Plant and Equipment & $\%$ \\
\hline (Mean) & 62 & (Mean) & 50 \\
\hline 1. Inadequacy of architectural specifications & 65 & $\begin{array}{c}\text { 1. Long break/position/stationary Un-used/redundancy - } \\
\text { rental cost }\end{array}$ & 55 \\
\hline $\begin{array}{l}\text { 2. Architectural drawings complexity- interpretation } \\
\text { time lag }\end{array}$ & 65 & $\begin{array}{l}\text { 2. Poor communication system within or between } \\
\text { gang(s) - time lag }\end{array}$ & 51 \\
\hline $\begin{array}{l}\text { 3. Ambiguity of structural drawings - interpretation } \\
\text { time lag }\end{array}$ & 64 & $\begin{array}{l}\text { 3. Lack of co-ordination within or between gang(s) - } \\
\text { redundancy/inefficiency }\end{array}$ & 51 \\
\hline 4. Inadequacy of structural engineering specifications & 61 & $\begin{array}{c}\text { 4. Breakdown during work in progress - } \\
\text { materials/labour wastes } \\
\end{array}$ & 50 \\
\hline 5. Inadequacy of electrical engineering specifications & 61 & 5. Possible repeated work for plant & 49 \\
\hline 6. Inadequacy of mechanical engineering specifications & 61 & $\begin{array}{l}\text { 6. Operation and plant position, traffic - materials. \& } \\
\text { labour wastes }\end{array}$ & 49 \\
\hline \multirow[t]{3}{*}{$\begin{array}{l}\text { 7. Inadequacy of estimator/quantity surveyor } \\
\text { specifications }\end{array}$} & 55 & 7. Delivery time \& redundancy period & 48 \\
\hline & & $\begin{array}{c}\text { 8. Un-experience operator - minimal } \\
\text { efficiency/productivity }\end{array}$ & 47 \\
\hline & & $\begin{array}{l}\text { 9. Uncoordinated skills between plant operator and the } \\
\text { controller }\end{array}$ & 46 \\
\hline
\end{tabular}


Table 4. Budgeting for wastes of different types of resources (\%)

\begin{tabular}{|c|c|c|c|c|c|c}
\hline & \multicolumn{2}{|c|}{$\begin{array}{c}\text { a) } \\
\text { Materials, (Ma) }\end{array}$} & \multicolumn{2}{c|}{$\begin{array}{c}\text { b) } \\
\text { Manpower, (Mp) }\end{array}$} & \multicolumn{2}{c}{$\begin{array}{c}\text { c) } \\
\text { Machinery, (Me) }\end{array}$} \\
\hline Strongly Agreed & 17 & \multirow{2}{*}{68} & 07 & \multirow{2}{*}{4} & 02 & 22 \\
& 51 & & 37 & & 20 & \\
\hline Agreed & 51 & &
\end{tabular}

Table 5. Allowance of wastefulness in deferent production information

\begin{tabular}{|c|c|c|c|c|c|c|c|c|c|c|}
\hline \multirow[b]{2}{*}{ Strongly Agreed } & \multicolumn{2}{|c|}{$\begin{array}{l}\text { a) Architectural } \\
\text { Drawings and } \\
\text { Spec }\end{array}$} & \multicolumn{2}{|c|}{$\begin{array}{c}\mathrm{b}) \\
\text { Structural } \\
\text { Drawings and } \\
\text { Spec. }\end{array}$} & \multicolumn{2}{|c|}{$\begin{array}{c}\text { c) } \\
\text { B. O. Q }\end{array}$} & \multicolumn{2}{|c|}{$\begin{array}{c}\text { d) } \\
\text { Mech. } \\
\text { Drawings and } \\
\text { Spec. }\end{array}$} & \multicolumn{2}{|c|}{$\begin{array}{c}\mathrm{e}) \\
\text { Elect. } \\
\text { Drawings and } \\
\text { Spec. }\end{array}$} \\
\hline & 02 & \multirow{2}{*}{56} & 05 & \multirow{2}{*}{53} & 03 & & 08 & \multirow{2}{*}{50} & 05 & \\
\hline Agreed & 54 & & 48 & & 49 & 52 & 42. & & 40 & 45 \\
\hline Undecided & \multicolumn{2}{|c|}{26} & \multicolumn{2}{|c|}{20} & \multicolumn{2}{|c|}{23} & \multicolumn{2}{|c|}{23} & \multicolumn{2}{|c|}{27} \\
\hline Less Agreed & \multicolumn{2}{|c|}{16} & \multicolumn{2}{|c|}{25} & \multicolumn{2}{|c|}{22} & \multicolumn{2}{|c|}{25} & \multicolumn{2}{|c|}{27} \\
\hline Disagreed & \multicolumn{2}{|c|}{02} & \multicolumn{2}{|c|}{02} & \multicolumn{2}{|c|}{03} & \multicolumn{2}{|c|}{02} & \multicolumn{2}{|c|}{01} \\
\hline Total & \multicolumn{2}{|c|}{100} & \multicolumn{2}{|c|}{100} & \multicolumn{2}{|c|}{100} & \multicolumn{2}{|c|}{100} & \multicolumn{2}{|c|}{100} \\
\hline
\end{tabular}

Table 6. Demography of personnel that indicated Interest to be interviewed and those interviewed

\begin{tabular}{|c|c|c|c|}
\hline $\begin{array}{c}\text { Respondents. } \\
\text { (Name Withheld })\end{array}$ & Status & Years of Experience & Comments \\
\hline 1$)$ & Contract Manager & Above 15 & Interviewed \\
\hline 2$)$ & Senior Bldg Manager & Above 15 & Interviewed \\
\hline 3$)$ & Project. Quantity Surveyor & Above 15 & Interviewed \\
\hline 4$)$ & Site manager & Between 11 -15 & Interviewed \\
\hline 5$)$ & Planning Manager & Above 15 & Interviewed \\
\hline 6$)$ & Project. Manager & Above 15 & Interviewed \\
\hline 7$)$ & Senior Project. Manager & Above 15 & Interviewed \\
\hline 8$)$ & Senior Contract Manager & Above 15 & Interviewed \\
\hline 9$)$ & Project. Manager & Above 15 & Not interviewed \\
\hline 10$)$ & Project. Manager & Between 11 - 15 & Not interviewed \\
\hline 11$)$ & Quantity Surveyor & Between 6 - 10 & Not interviewed \\
\hline 12$)$ & Project. Manager & Between 6 -10 & Not interviewed \\
\hline 13$)$ & Planning Manager & Above 15 & Not interviewed \\
\hline 14$)$ & Site Manager & Above 15 & Not interviewed \\
\hline 15$)$ & Project Manager & Above 15 & Not interviewed \\
\hline
\end{tabular}


Table 7. Summary of causes, rationales and solutions proposed on the scenarios of budgeting for wastes syndromes, (BWS)

\begin{tabular}{|c|c|c|}
\hline $\begin{array}{c}\text { Causes of Budgeting for Wastes' } \\
\text { Syndromes }\end{array}$ & $\begin{array}{l}\text { Rationales that make the site } \\
\text { participants belief that the } \\
\text { resources' wastes are inevitable }\end{array}$ & $\begin{array}{l}\text { Factors that will significantly } \\
\text { reduce construction participants' } \\
\text { beliefs and resources wastefulness }\end{array}$ \\
\hline Inability to ensure labour efficiency & $\begin{array}{l}\text { Construction environment and due } \\
\text { to environmental factors which } \\
\text { cannot be predicted precisely }\end{array}$ & $\begin{array}{l}\text { Motivation and Incentives towards } \\
\text { wastes reduction }\end{array}$ \\
\hline $\begin{array}{l}\text { Ambiguous and inadequacy of } \\
\text { production information }\end{array}$ & $\begin{array}{l}\text { Wastes occurrence due to } \\
\text { unavoidable human errors }\end{array}$ & $\begin{array}{l}\text { Setting and striving to achieve } \\
\text { wastes reduction targets }\end{array}$ \\
\hline $\begin{array}{l}\text { Rigidity of the design team over } \\
\text { production information }\end{array}$ & $\begin{array}{l}\text { Most project sites are in congested } \\
\text { or remote areas }\end{array}$ & $\begin{array}{l}\text { Reliable record and information on } \\
\text { similar previous project executed }\end{array}$ \\
\hline Construction project location & $\begin{array}{l}\text { To insufficient time to plan } \\
\text { adequately at project inception }\end{array}$ & $\begin{array}{l}\text { Training towards executing project } \\
\text { efficiently and be resourceful }\end{array}$ \\
\hline $\begin{array}{l}\text { Lack of skilled manpower resulting } \\
\text { in the utilisation of semi-skilled } \\
\text { workforce }\end{array}$ & $\begin{array}{l}\text { Lack of adequate experienced and } \\
\text { skilled labour in the construction } \\
\text { industry }\end{array}$ & $\begin{array}{c}\text { Awareness of resources' wastes } \\
\text { implication and wastes reduction } \\
\text { benefits }\end{array}$ \\
\hline \multicolumn{3}{|l|}{$\begin{array}{l}\text { Habitual alterations and } \\
\text { modifications }\end{array}$} \\
\hline \multicolumn{3}{|l|}{ Avoidance of liquidation damage } \\
\hline \multicolumn{3}{|l|}{ Short project delivery time } \\
\hline \multicolumn{3}{|l|}{ External Factors Control Limitation } \\
\hline \multicolumn{3}{|l|}{$\begin{array}{l}\text { Lack of new innovative skilled } \\
\text { workers }\end{array}$} \\
\hline \multicolumn{3}{|l|}{$\begin{array}{l}\text { Labour only sub-contractors' } \\
\text { carefree attitude }\end{array}$} \\
\hline $\begin{array}{c}\text { Client unaware or nonchalant } \\
\text { attitude }\end{array}$ & & \\
\hline
\end{tabular}

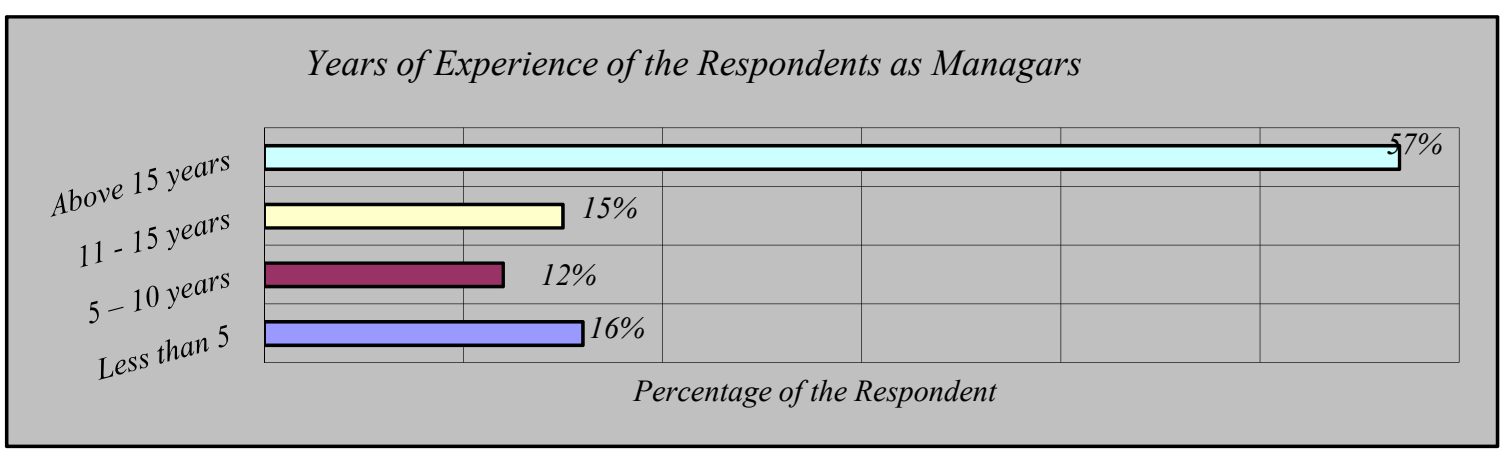

Figure 1. Years of experience of the respondents as managers in the construction sector 


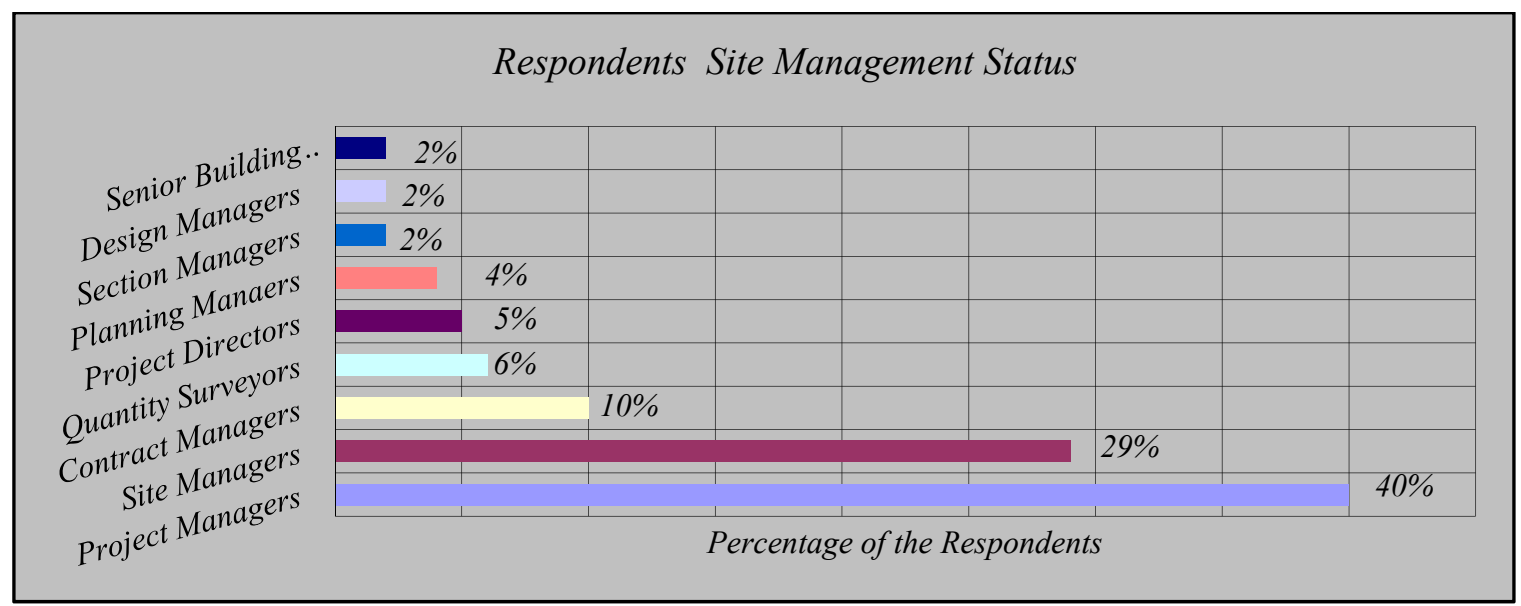

Figure 2. Respondents site management status

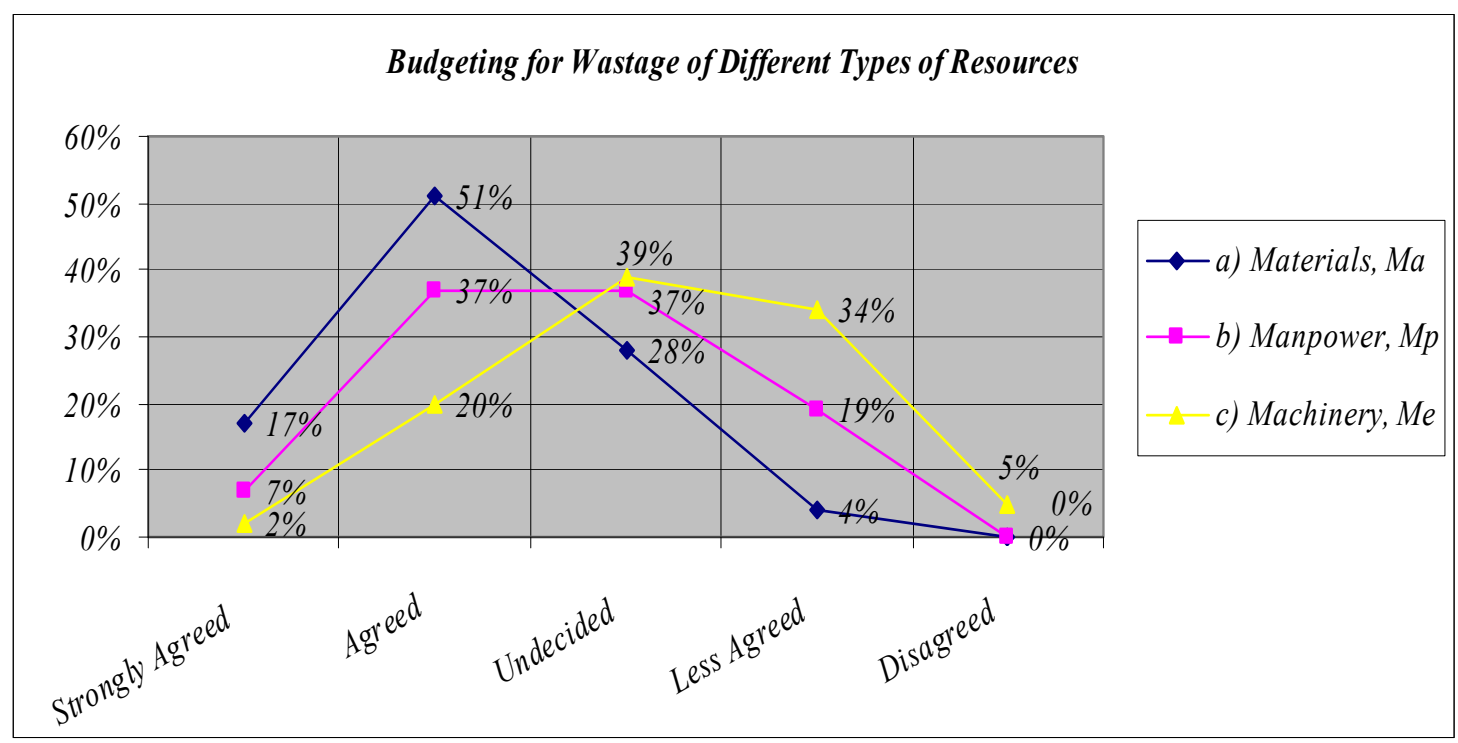

Figure 3. Budgeting for wastes of different types of resources

(summation of strongly agreed and agreed percentages)

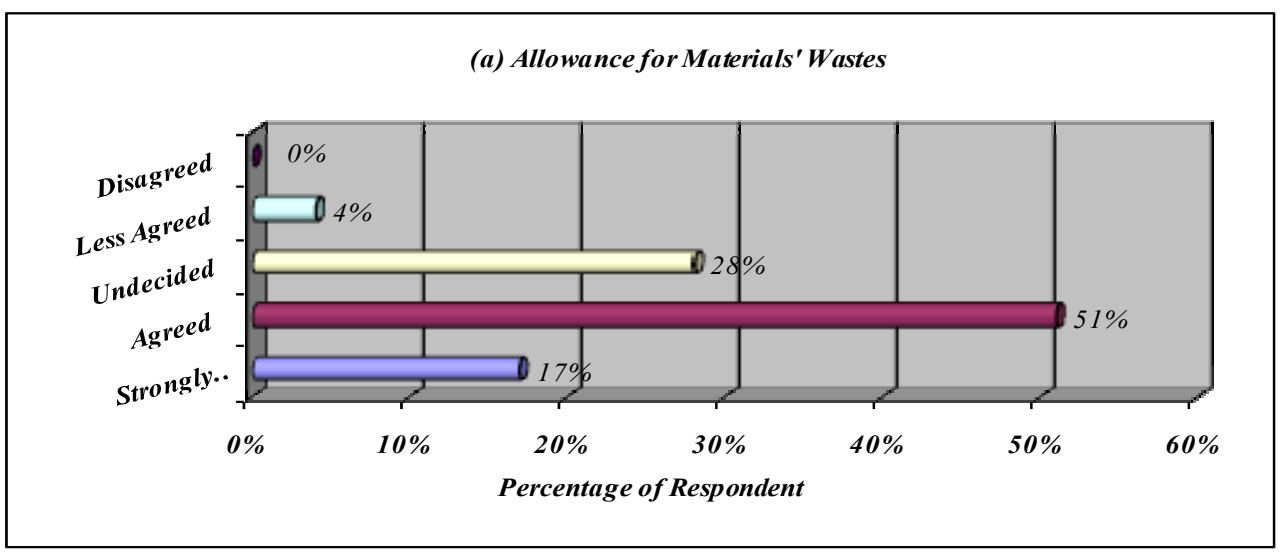



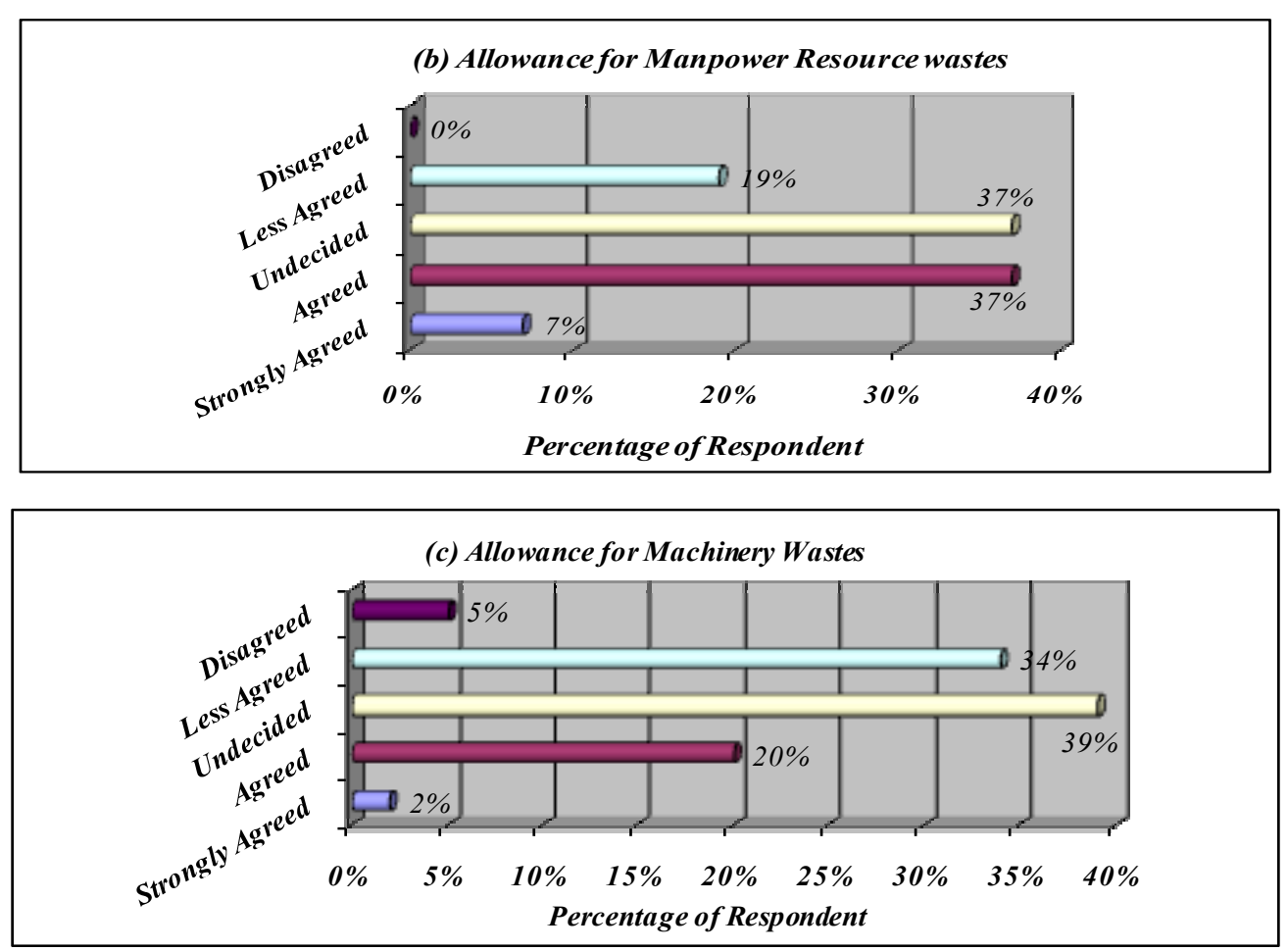

Figure 4 (a-c). Respondents' agreement on budgeting for wastes of different types of resources

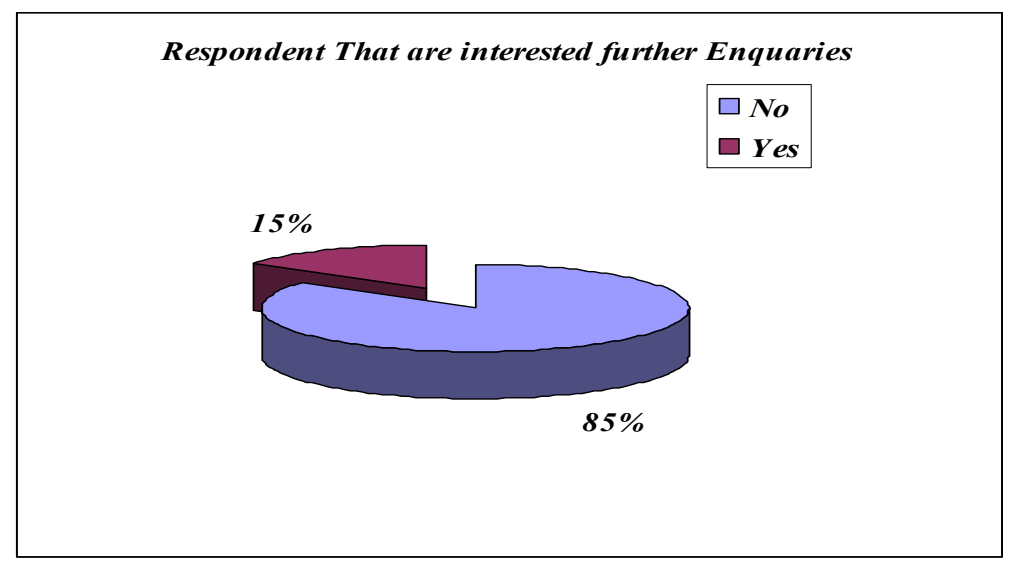

Figure 5. Respondents that showed interest in being contacted for further enquiries 